\title{
MENGUKUR KONTRIBUSI LANGGANAN E-JOURNAL SCIENCEDIRECT TERHADAP PRODUKTIVITAS PERGURUAN TINGGI MENGGUNAKAN STUDI BIBLIOMETRIK: STUDI KASUS UNIVERSITAS ANDALAS
}

\author{
Andi Saputra \\ UPT Perpustakaan Universitas Andalas \\ Korespondensi: andisaptra@gmail.com
}

Diajukan: 12-03-2018; Direview: 26-05-2018; Diterima: 28-08-2018; Direvisi: 20-10-2018

\begin{abstract}
This study aims to measure the level of productivity of authors affiliated with Andalas University in journal published by ScienceDirect, to illustrate the level of contribution and utilization rate of e-journal subscriptions at Andalas University. Descriptive bibliometric method is used to measure the researcher's performance. Data is retrieved over the last 10 years. Data collection techniques from the ScienceDirect use advanced search facilities, typing the "universitas andalas" and "andalas university" keywords in the search field for the affiliation category specific to the Journal article type. Author productivity is measured using descriptive statistical methods presented based on geographic (faculty), time period (year), publisher, author and collaboration pattern, and field of science. The results of this study indicate that although in the last 10 years, numbers of Andalas University publications in ScienceDirect trend tends to increase but in terms of the number is still small, only an average of 10 articles a year. The authorship collaboration pattern reached 0,82 with the number of collaborations with outside authors reaching $78 \%$. Distribution of users is also not evenly distributed. Only two faculties have the most benefits of ScienceDirect, Faculty of Engineering and FMIPA.
\end{abstract}

\begin{abstract}
ABSTRAK
Penelitian ini bertujuan untuk mengukur tingkat produktivitas penulis yang berafiliasi dengan Universitas Andalas di jurnal terbitan ScienceDirect, untuk menggambarkan tingkat kontribusi dan tingkat pemanfaatan langganan e-journal di Universitas Andalas. Metode bibliometrik deskriptif digunakan untuk mengukur kinerja peneliti. Data diambil dalam rentang 10 tahun terakhir. Teknik pengambilan data dari ScienceDirect, menggunakan fasilitas pencarian mahir, dengan mengetikkan kata kunci "universitas andalas" dan "andalas university" pada kolom pencarian untuk kategori affiliation khusus untuk jenis artikel jurnal. Produktivitas penulis diukur menggunakan metode statistik deskriptif yang disajikan berdasarkan geografis (fakultas), periode waktu (tahun), penerbit, penulis dan pola kolaborasi, dan bidang ilmu. Hasil penelitian menunjukkan bahwa meskipun dalam 10 tahun terakhir jumlah publikasi Universitas Andalas di ScienceDirect cenderung meningkat, tetapi dari segi jumlah masih sedikit, ratarata 10 artikel pertahun. Pola kolaborasi kepenulisan mencapai 0,82 dengan jumlah kolaborasi penulis luar mencapai $78 \%$. Sebaran penggunanya juga belum merata, hanya dua fakultas yang paling banyak merasakan manfaat keberadaan ScienceDirect, yaitu Fakultas Teknik dan FMIPA.
\end{abstract}

Keywords: Bibliometric; Journal; ScienceDirect; Article; Author; Access; Universitas Andalas

\section{PENDAHULUAN}

Pernyataan Menristekdikti terkait pemberhentian langganan electronic journal (e-journal) oleh Perguruan Tinggi Negeri (PTN) dan Perguruan Tinggi Swasta (PTS) beberapa waktu yang lalu telah menimbulkan perdebatan. Besarnya biaya langganan jurnal yang dikeluarkan dianggap sebagai pemborosan karena sebagian besar jurnal telah dilanggan oleh Perpustakaan Nasional RI (jppn.com., 2017). Baik PTN maupun PTS menilai besarnya biaya langganan ejournal tidak sebanding dengan manfaat yang diterima oleh sivitas akademik perguruan tinggi. 
Universitas Andalas (Unand) telah mengalokasikan anggaran yang cukup besar untuk langganan database e-journal dari ScienceDirect, yang merupakan penerbit terbesar yang menerbitkan $e$ journal bereputasi internasional (ScienceDirect, 2018). Menurut staf Unit Layanan Pengadaan (ULP) Unand, ScienceDirect merupakan platform terbitan Elsevier dengan porsi e-journal terbesar yang dilanggan oleh Unand dan besarnya anggaran mencapai $80 \%$.

Penelitian terdahulu terhadap pemanfaatan langganan jurnal online dengan menyebarkan angket ke responden telah dilakukan oleh Harisyah \& Azwar (2015) dan analisis sitiran oleh Maryatun \& Irianti (2016). Pada penelitian tersebut dilakukan analisis tentang pola publikasi dan tingkat produktivitas penulis dari PTN/PTS terhadap e-journal yang dilanggan dengan pendekatan bibliometrik. Studi bibliometrik merupakan metode yang paling banyak digunakan untuk menganalisis pola publikasi e-journal berbasis platform tertentu, seperti ScienceDirect, ProQuest, Ebsco, Scopus, Springer, dsb. Metode bibliometrik dimulai sejak tahun 1960an dan di awal tahun 1980an mulai berevolusi menjadi displin ilmu yang digunakan untuk profil penelitian yang lebih spesifik (Glanzel, 2003).

Studi bibliometrik dapat digunakan untuk: (a) mengukur produktivitas publikasi berdasarkan kategori tertentu menggunakan metode matematika dan statistika (Sulistyo-Basuki, 2016); (b) mengukur produktivitas ilmiah dan analisis profil publikasi, yang dapat ditentukan dari perspektif yang berbeda, misalnya bidang subjek tertentu, lembaga atau sektor, serta sumber pendanaan penelitian (Glanzel, 2003); (c) mengukur produktivitas pengarang bidang ilmu perpustakaan dan informasi dengan Hukum Lotka (Nelisa, 2012); (d) menganalisis artikel ilmiah bidang lingkungan yang ada di Indonesia dan riset energi internasional yang dipublikasikan di ScienceDirect (Himawanto, 2017, 2016a); (e) menganalisis terhadap pola dan tren publikasi artikel yang diterbitkan pada jurnal tertentu (Natakusumah, 2016; Rahayu \& Saleh, 2017); (f) menganalisis terhadap publikasi bidang ilmu tertentu di database Scopus (Tupan, 2017; Sánchez, Rama, \& García, 2017). Penelitian ini fokus pada kajian penerbit, wilayah, dan subjek. Penelitian ini menggunakan metode bibliometrik untuk menganalisis kinerja peneliti Unand melalui e-journal terbitan ScienceDirect. ScienceDirect dipilih karena platform ini memiliki porsi langganan terbesar Unand dalam beberapa tahun terakhir. Tujuan penelitian ini adalah untuk mengukur tingkat produktivitas penulis yang berafiliasi di Unand pada e-journal terbitan ScienceDirect.

\section{TINJAUAN PUSTAKA}

\subsection{Studi Bibliometrik}

Untuk menghindari kerancuan istilah statistical bibliography dan bibliography of statistica, Alan Pritchard membuat istilah baru yang disebut bibliometrik. Bibliometrik merupakan metode statistika dan matematika terhadap buku serta media komunikasi lain yang diterapkan dalam segala bentuk media komunikasi terekam, baik berupa grafis maupun elektronik. Bibliometrik bertujuan menjelaskan proses komunikasi tertulis dan sifat serta arah pengembangan saran deskriptif perhitungan dan analisis berbagai faset komunikasi. Ilmu bibliometrik ada dua, yaitu: (a) bibliometrik deskriptif, untuk mengkaji produktivitas, baik berdasarkan geografis, periode waktu, maupun disiplin ilmu; dan (b) bibliometrik evaluatif, untuk menghitung penggunaan literatur topik, subjek, atau disiplin ilmu tertentu (SulistyoBasuki, 2016).

Metode statistika dan matematika tidak hanya digunakan untuk koleksi konvensional tetapi juga untuk kajian publikasi elektronik. Sebagian besar peneliti mengkaji tentang pola publikasi ilmiah yang ada di database jurnal internasional bereputasi seperti ScienceDirect, 
EBSCO, ProQuest, Springer, dan Scopus. Himawanto (2016a) telah melakukan tentang produktivitas peneliti Indonesia di riset energi internasional yang dipublikasikan di jurnal terbitan ScienceDirect dalam rentang waktu satu decade; Himawanto (2016b) telah meneliti tentang kinerja Indonesia pada riset konsorsium energi di Jurnal Ilmiah Internasional; Rahayu \& Saleh (2017) menggunakan metode bibliometrik untuk mengukur sebaran topik penelitian pada Jurnal Hayati yang diterbitkan dalam rentang waktu tahun 2012 hingga 2016; Sánchez, Rama, \& García (2017) menggunakan metode bibliometrik untuk menganalisis publikasi tentang "wine tourism" yang ada di pangkalan data Scopus dan WoS; dan Tupan (2017) menggunakan metode saintometrik untuk menganalisis pertumbuhan literatur bidang ilmu perpustakaan dan informasi berbasis database Scopus tahun 1996-2016.

\subsection{ScienceDirect}

ScienceDirect merupakan platform terkemuka dari Elsevier, penerbit online terkemuka yang berpusat di Belanda dalam literatur ilmiah hasil peer-review. Sampai akhir tahun 2017, ScienceDirect masih menjadi platform online dengan jumlah terbitan jurnal terbanyak di dunia, terdiri dari 3.976 jurnal dan 48.124 buku (Science Direct, 2018). Salah satu upaya untuk menghitung jumlah publikasi penulis Unand di ScienceDirect adalah dengan melihat jurnal yang memuat artikel dan karekteristik yang menggambarkan kontribusi dan pola publikasinya.

\section{METODE}

Penelitian ini menggunakan metode bibliometrik deskriptif untuk mengukur kinerja peneliti yang berafiliasi dengan Unand di jurnal terbitan ScienceDirect. Data diambil dari pangkalan data ScienceDirect dalam dalam rentang waktu 10 tahun terakhir (2008-2017). Teknik pengambilan data menggunakan fasilitas pencarian mahir (advanced search), dengan menggunakan kata kunci "universitas andalas" dan "andalas university" pada kolom pencarian untuk kategori affiliation khusus untuk jenis artikel jurnal. Analisis data dilakukan secara kuantitatif, yang mengacu pada pendapat Sulistyo-Basuki (2016) yaitu studi bibliometrik digunakan untuk menentukan garis haluan pengadaan barbasis kebutuhan dalam batas anggaran belanja. Dalam hal ini, data bibliografi artikel hasil pencarian dianalisis dengan cara: (1) menghitung jumlah publikasi berdasarkan tahun terbit; (2) mengelompokkan artikel berdasarkan nama jurnal dan mengambil 10 jurnal terbitan Unand; (3) menghitung data jurnal Unand yang terindeks Scopus per-Oktober 2017; (4) mengukur produktivitas penulis menggunakan statistik deskriptif dalam bentuk data geografis (fakultas), periode waktu (tahun), penerbit, penulis; (5) menghitung tingkat kolaborasi penulis dari Unand secara kuantitatif, dengan rumus Subramanyam (1983), sebagai berikut.

$$
\begin{array}{cl}
\qquad C=\frac{N M}{N M+N S} \\
\text { Keterangan: } \\
\text { C } & =\text { tingkat kolaborasi peneliti, nilai } \mathrm{C} \text { berada pada interval nol sampai dengan satu } \\
\mathrm{Nm} & =\text { total hasil penelitian dari peneliti yang dilakukan secara berkolaborasi } \\
\mathrm{Ns} & =\text { total hasil penelitian dari peneliti yang dilakukan secara individual }
\end{array}
$$

Nilai $\mathrm{C}$ yang diperoleh berdasarkan metode di atas dapat dikategorikan:

a) Bila nilai $\mathrm{C}$ sama dengan nol $(\mathrm{C}=0)$ maka seluruh kegiatan penelitian dilakukan secara individu (peneliti tunggal) atau tidak ada satupun penelitian yang dilakukan secara kolaborasi. 
b) Bila nilai $\mathrm{C}$ lebih besar dari 0 dan kurang dari setengah $(0<\mathrm{C}<0,5)$ maka kegiatan penelitian yang dilakukan secara individu lebih banyak dibandingkan dengan penelitian yang dilakukan secara kolaborasi.

c) Bila nilai $\mathrm{C}$ sama dengan setengah $(\mathrm{C}=0,5)$ maka jumlah antara penelitian individu dengan penelitian berkolaborasi seimbang.

d) Bila nilai $\mathrm{C}$ lebih besar dari setengah dan kurang dari satu $(0,5<\mathrm{C}<1)$ maka kegiatan penelitian secara kolaborasi lebih banyak dibandingkan dengan penelitian individu.

e) Bila nilai $\mathrm{C}$ sama dengan satu $(\mathrm{C}=1)$ maka seluruh kegiatan penelitian dilakukan secara kolaborasi. Selain untuk mengukur tingkat kolaborasi, perhitungan juga untuk mengetahui kontribusi penulis dari luar terhadap hasil penelitian yang dilakukan oleh penulis dari Unand.

\section{HASIL DAN PEMBAHASAN}

\subsection{Hasil Penelitian}

Metode studi bibliometrik untuk mengukur publikasi ilmiah dalam bentuk e-journal dengan beberapa indikator, diantaranya untuk menghitung produktivitas berdasarkan penerbit, periode waktu, penulis, geografis, dan kolaborasi (Himawanto, 2016a; Sánchez, Rama, \& García, 2017; Rahayu \& Saleh, 2017; Glänzel \& Schoepflin, 1999; Tupan, 2017). Pada penelitian ini, indikator yang digunakan untuk mengukur produktivitas penulis Unand adalah periode waktu (publikasi dalam rentang waktu 10 tahun terakhir), penerbit, penulis, kolaborasi, dan geografi. Khusus untuk geografi, pemetaan dilakukan berdasarkan fakultas asal penulis.

\section{1) Jumlah artikel publikasi Unand}

Rentang waktu satu dekade (10 tahun) merupakan periode waktu yang cukup untuk mengukur kinerja sebuah institusi (Himawanto, 2016a). Walaupun ada yang menggunakan rentang waktu 5 tahun (Rahayu \& Saleh, 2017) dan sampai 20 tahun (Tupan, 2017). Dalam rentang waktu tersebut, terdapat 95 artikel dengan afiliasi penulis dari Unand. Publikasi paling banyak pada tahun 2017, yaitu 22 artikel. Jumlah artikel ini meningkat dua kali lipat jika dibandingkan tahun 2016. Gambar 1 menunjukkan jumlah artikel penulis Unand di ScienceDirect.

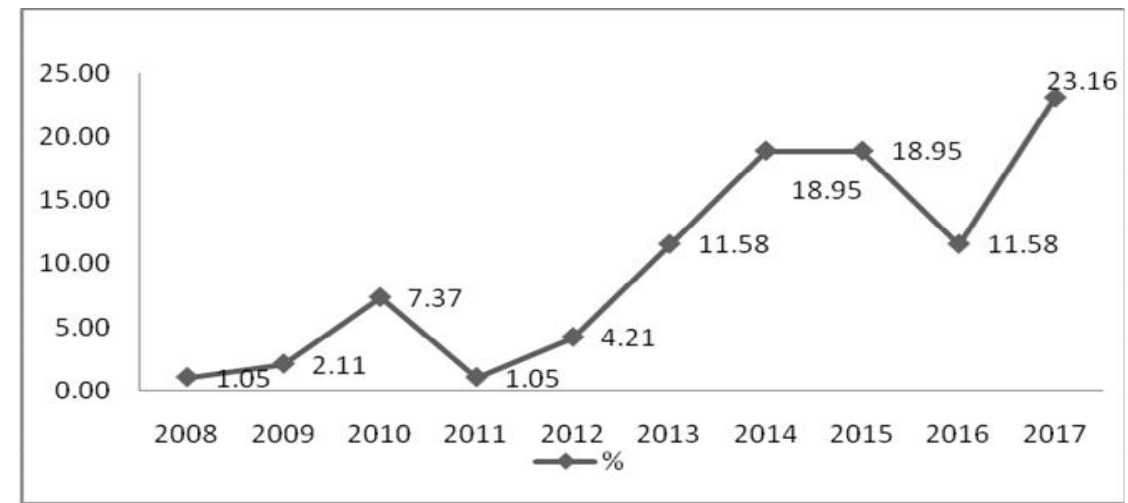

Gambar 1. Jumlah publikasi Unand tahun 2008-2017

\section{2) Jumlah publikasi yang memuat artikel penulis Unand}

Sampai akhir tahun 2017, e-journal yang memuat artikel penulis dari Unand di ScienceDirect mencapai 4.000 artikel. Dari jumlah tersebut, ada 95 artikel yang tersebar ke-59 penerbit. Tabel 1 menunjukkan 10 besar jurnal di ScienceDirect yang paling banyak memuat artikel penulis dari Unand. 
Tabel 1. Publikasi yang Memuat Artikel Penulis Unand di ScienceDirect

\begin{tabular}{|c|l|c|c|}
\hline No. & \multicolumn{1}{|c|}{ Judul Publikasi } & Jumlah & $\begin{array}{c}\text { Persentase } \\
(\mathbf{\%})\end{array}$ \\
\hline 1 & Procedia - Social and Behavioral Sciences & 7 & 7,37 \\
\hline 2 & Procedia Engineering & 7 & 7,37 \\
\hline 3 & Atmospheric Research & 6 & 6,32 \\
\hline 4 & Agriculture and Agricultural Science Procedia & 5 & 5,26 \\
\hline 5 & Energy Procedia & 3 & 4,21 \\
\hline 6 & Journal of Cleaner Production & 3 & 3,16 \\
\hline 7 & Procedia CIRP & 3 & 3,16 \\
\hline 8 & Procedia Chemistry & 3 & 3,16 \\
\hline 9 & Procedia Environmental Sciences & 3 & 3,16 \\
\hline 10 & Asian Pacific Journal of Tropical Biomedicine & 2 & 2,11 \\
\hline
\end{tabular}

Dari total 59 penerbit, diketahui Procedia-Social and Behavioral Sciences dan Procedia Engineering paling banyak menerbitkan artikel dari Unand, yaitu 7 artikel (7,37\%). Kemudian disusul oleh Atmospheric Research, 6 artikel (6,32\%) dan 56 penerbit yang menerbitkan tidak lebih dari 5 artikel.

\section{3) Jumlah jurnal yang terindeks Scopus}

Sampai saat ini, Scopus masih menjadi standar rujukan jurnal internasional bereputasi. Meskipun ScienceDirect dan Scopus sama-sama produk dari Elsevier, tetapi tidak semua jurnal terbitan ScienceDirect terindeks di Scopus. Untuk itu, perlu dilakukan penelusuran jurnal terbitan ScienceDirect di Scopus. Tabel 2 menunjukkan artikel jurnal yang memuat artikel penulis Unand di Scopus per-Oktober 2017 (Scopus Source List, 2017).

Tabel 2. Artikel Penulis Unand yang Terindeks Scopus

\begin{tabular}{|c|l|c|c|}
\hline \multirow{2}{*}{ No. } & \multirow{2}{*}{ Keterangan } & \multicolumn{2}{c|}{ Jumlah } \\
\cline { 3 - 4 } & & Penerbit & Artikel \\
\hline 1 & Terindek Scopus & 46 & 57 \\
\hline 2 & Tidak terindek Scopus & 13 & 38 \\
\hline \multicolumn{2}{|c|}{ Total } & 59 & 95 \\
\hline
\end{tabular}

\section{4) Jumlah kolaborasi kepenulisan}

Setelah dilakukan perhitungan terhadap artikel penulis Unand pada jurnal di ScienceDirect yang terindeks Scopus diketahui tingkat kolaborasinya sebesar 0,82, yang berarti bahwa kegiatan penelitian lebih banyak dilakukan secara kolaborasi jika dibandingkan dengan penelitian secara individu. Dari total 95 artikel diketahui ada $18 \%$ hasil penulis tunggal dan $82 \%$ hasil kolaborasi. Pola kolaborasinya terlihat sesama penulis dari Unand sebesar $4 \%$ dan 78\% yang berkolaborasi dengan penulis luar Unand. Gambar 2 menunjukkan perbandingan kolaborasi kepenulisan. 


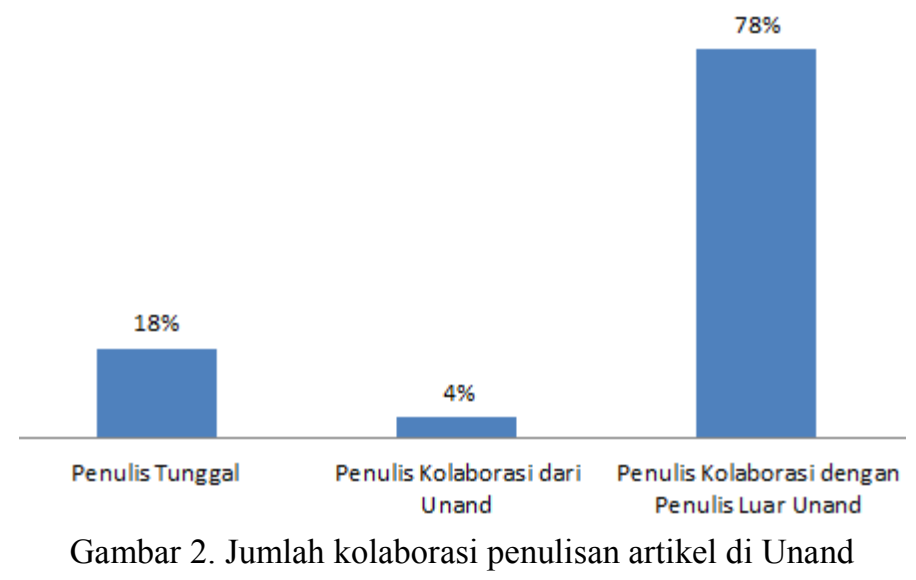

Hasil perhitungan terhadap jumlah keterlibatan penulis dalam kolaborasi menunjukkan $38 \%$ berkolaborasi lebih dari 5 penulis; $19 \%$ berkolaborasi 4 penulis; 20\% berkolaborasi 3 penulis; dan 19\% berkolaborasi 2 penulis.

\section{5) Jumlah asal fakultas penulis artikel}

Salah satu bagian dari kajian bibliometrik deskriptif adalah menghitung produktivitas berdasarkan geografis penulis. Ketika basis kajiannya negara, maka pembagian geografisnya berdasarkan wilayah atau instansi asal penulis. Ketika basis kajiannya perguruan tinggi, maka wilayah geografis penulisnya berbasis pada bidang ilmu atau fakultas asal penulis. Gambar 3 menunjukkan jumlah publikasi berdasarkan fakultas penulis Unand.

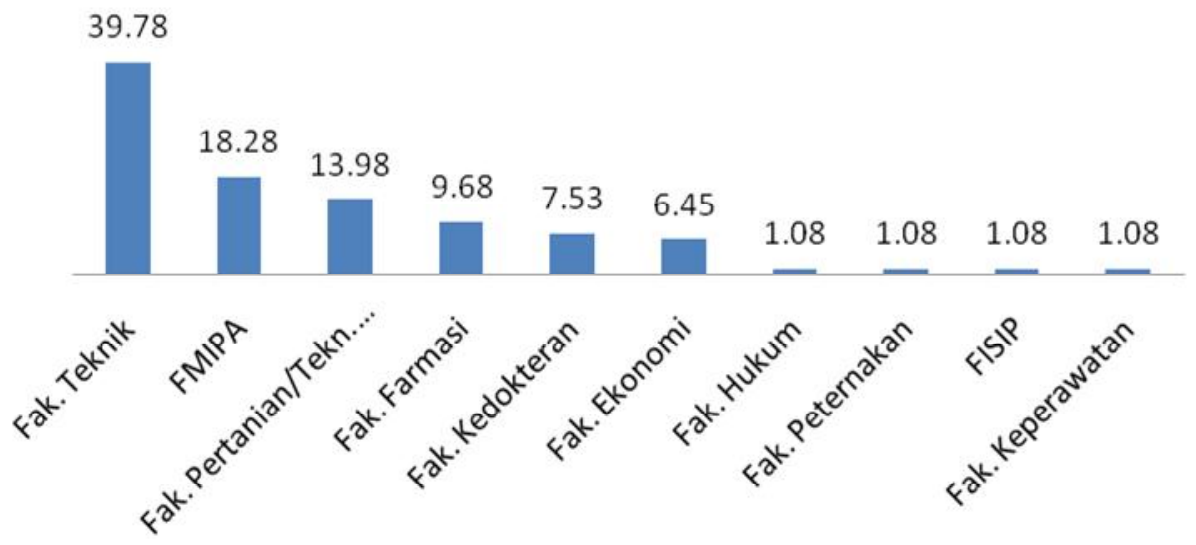

Gambar 3. Jumlah fakultas penulis artikel

\section{6) Jumlah penulis artikel terbanyak di ScienceDirect}

Dari jumlah keseluruhan 95 artikel diketahui ada 140 penulis artikel penulis Unand atau $78 \%$ artikel ditulis secara kolaborasi oleh dua orang atau lebih. Tabel 3 menunjukkan jumlah publikasi dengan dua penulis atau lebih yang ditulis oleh penulis Unand. 
Tabel 3. Daftar Penulis Unand Berkolaborasi di Jurnal ScienceDirect

\begin{tabular}{|c|l|l|c|c|}
\hline No. & \multicolumn{1}{|c|}{ Nama Penulis } & \multicolumn{1}{|c|}{ Fakultas } & Jumlah & $\begin{array}{c}\text { Persentase } \\
(\%)\end{array}$ \\
\hline 1 & Marzuki & MIPA & 6 & 6,32 \\
\hline 2 & Lusi Susanti & Teknik & 5 & 5,26 \\
\hline 3 & Feri Afrinaldi & Teknik & 4 & 4,21 \\
\hline 4 & Fadjar Goembira & Teknik & 3 & 3,16 \\
\hline 5 & Mai Efdi & MIPA & 3 & 3,16 \\
\hline 6 & Marlina & Farmasi & 3 & 3,16 \\
\hline 7 & Muhammad Makky & Pertanian & 3 & 3,16 \\
\hline 8 & Refdinal Nazir & Teknik & 2 & 3,16 \\
\hline 9 & Alizar Hasan & Teknik & 2 & 2,11 \\
\hline 10 & Annike Lutfia Vilsi & Teknik & 2 & 2,11 \\
\hline 11 & Dachriyanus & Farmasi & 2 & 2,11 \\
\hline 12 & Dayar Arbain & Farmasi & 2 & 2,11 \\
\hline 13 & Elita Amrina & Teknik & 2 & 2,11 \\
\hline 14 & I Piet Iskandar & Kedokteran & 2 & 2,11 \\
\hline 15 & Novelina & Pertanian & 2,11 \\
\hline 16 & Rendy Thamrin & Teknik & 2,11 \\
\hline 17 & Rudi Febriamansyah & Teknologi Pertanian & 2 & 2,11 \\
\hline 18 & Taufik & Teknik & & \\
\hline & & & 2 & 2 \\
\hline
\end{tabular}

\subsection{Pembahasan Penelitian}

Gambar 1 menunjukkan bahwa ada 95 artikel yang telah diterbitkan dalam 10 tahun terakhir. Meskipun pernah mengalami penurunan pada tahun 2011 dan tahun 2016, namun jumlah artikel yang dihasilkan oleh penulis Unand setiap tahun cenderung meningkat, khususnya pada tahun 2013 dan 2017 hingga 100\%. Sulistyo-Basuki (2016) mengatakan bahwa salah satu manfaat studi bibliometrik adalah untuk menentukan garis haluan pengadaan barbasis kebutuhan dalam batas anggaran belanja. Maka dari segi jumlah, dengan rata-rata hanya 10 artikel per-tahun, manfaat yang diperoleh belum sebanding dengan besaran anggaran yang dialokasikan oleh Unand untuk langganan jurnal di ScienceDirect.

Berdasarkan penerbit, seluruh artikel penulis Unand tersebar ke-59 penerbit dengan ratarata satu penerbit menerbitkan kurang dari 2 artikel, yang berarti bahwa publikasi penulis Unand tersebar ke berbagai jurnal. Penulis artikel tidak hanya fokus pada jurnal tertentu tetapi juga terbitan lain yang terindeks Scopus. Artikel terbanyak diterbitkan pada Procedia - Social and Behavioral Sciences dengan jumlah 7 artikel. Dari 10 jurnal yang menerbitkan artikel penulis Unand diketahui hanya Atmospheric Research yang terindeks Scopus, dan artikel lainnya diterbitkan dalam bentuk e-proceeding, seperti Procedia-Social and Behavioral Sciences, Procedia Engineering, Procedia (CIRP), Energy Procedia, dan Procedia Chemistry.

Tabel 2 menunjukkan bahwa dari total 59 jurnal yang memuat artikel penulis Unand diketahui ada 46 artikel (78\%) terindeks Scopus dan 12\% tidak terindeks Scopus. Apabila dihitung berdasarkan jumlah artikel, diketahui 57 artikel (60\%) yang diterbitkan oleh jurnal terindeks Scopus dan 38 artikel (40\%) diterbitkan oleh penerbit jurnal yang tidak terindeks Scopus. Penyebabnya bahwa sebagian artikel yang tidak terindeks Scopus diterbitkan dalam bentuk e-proceeding sehingga jumlah persentase artikel jurnal yang terindeks Scopus relatif 
lebih rendah. Saputra (2018) mengatakan bahwa untuk meningkatkan peringkat publikasi Unand di Scopus, yang saat ini ada pada peringkat 13, salah satu upayanya adalah mendorong penulis Unand untuk mempublikasikan artikel jurnal yang terindeks Scopus.

Berdasarkan pola kepenulisan diketahui ada $82 \%$ artikel penulis Unand yang merupakan hasil kolaborasi, dan sebagian besar kolaborasinya (78\%) dilakukan dengan penulis dari luar Unand dan 4\% ditulis dengan sesama penulis dari Unand. Tingginya tingkat kolaborasi dengan penulis luar disebabkan artikel ditulis pada saat penulis melaksanakan tugas belajar-sehingga mereka memiliki wawasan dan jaringan akademik yang luas.

Berdasarkan fakultas asal penulis, diketahui bahwa artikel penulis Unand yang paling banyak di ScienceDirect berasal dari Fakultas Teknik (39,78\%), kemudian diikuti oleh penulis artikel yang berasal Fakultas Matematika dan Ilmu Pengetahuan Alam (18,28\%) dan Fakultas Pertanian/Teknologi Pertanian (13,98\%). Pemanfaataan jurnal di ScienceDirect paling banyak dimanfaatkan oleh peneliti atau dosen Unand yang berasal dari Fakultas Teknik dan FMIPA (hampir 60\%). Misalnya Marzuki (FMIPA) telah mempublikasikan 6 artikel; Lusi Susanti (Fakultas Teknik) telah mempublikasikan 5 artikel; Feri Afrinaldi (Fakultas Teknik) telah mempublikasikan 4 artikel; dan 137 penulis telah mempublikasikan tidak lebih dari 3 artikel.

Berdasarkan bidang ilmu atau subject di ScienceDirect terlihat bahwa publikasi yang menjadi tujuan penulis artikel Unand lebih fokus pada bidang Physical Sciences and Engineering dan Life Sciences (80\%) dan selebihnya bidang Health Sciences dan Social Sciences and Humanities.

\section{KESIMPULAN}

Dalam satu dekade terakhir terlihat bahwa tren publikasi Unand di ScienceDirect jumlahnya cenderung meningkat, mencapai 95 artikel. Namun dilihat dari jumlahnya terlihat masih sedikit dan belum mengalami peningkatan secara signifikan, rata-rata hanya 10 artikel per-tahun. Jumlah publikasi tersebut belum sebanding dengan besarnya alokasi anggaran yang dianggarkan untuk berlangganan ScienceDirect. Tingkat kolaborasi penulis mencapai 0,82 dan 95\% merupakan hasil kolaborasi dengan penulis dari luar Unand. Dilihat dari sisi pemanfaatan jurnal di ScienceDirect, penerima manfaat belum merata karena artikel yang dipublikasikan 60\%nya berasal dari Fakultas Teknik dan FMIPA (dari jumlah 15 fakultas di Unand). Berdasarkan subjeknya diketahui $80 \%$ publikasi penulis Unand fokus pada bidang Physical Sciences and Engineering dan Life Sciences. Saran penulis untuk memaksimalkan pemanfaatan langganan e-journal terbitan ScienceDirect, antara lain: (a) menyelenggarakan sosialisasi ke setiap fakultas di Unand terkait dengan langganan e-journal; (2) perlu mengadakan pelatihan online research skill secara berkala mengenai cara mengakses, mengelola, dan menulis jurnal bagi sivitas akademika Unand. 


\section{DAFTAR PUSTAKA}

Glänzel, Wolfgang, \& Urs Schoepflin. 1999. A Bibliometric Study of Reference Literature in the Sciences and Social Sciences. Parts of This Study Have Been Presented at the 5th International Conference on Scientometrics and Informetrics, Held in River Forest, Illinois, June 7-10, 1995.1. Information Processing \& Management 35 (1): 31-44. https://doi.org/10.1016/S0306-4573(98)00028-4.

Harisyah, Harisyah, \& Muhammad Azwar. 2015. Pemanfaatan Jurnal Elektronik oleh Mahasiswa Fakultas Kedokteran Universitas Hasanuddin. Jurnal Ilmu Perpustakaan \& Informasi KHIZANAH AL-HIKMAH, 3 (June): 79-88. https://doi.org/10.24252/kah.v3ila7.

Himawanto. 2016a. Produktivitas Penulis Indonesia di Riset Energi Internasional (Kajian Jurnal ScienceDirect). Khizanah Al-Hikmah: Jurnal Ilmu Perpustakaan, Informasi, dan Kearsipan, 4 (1): 1-23. https://doi.org/10.24252/kah.v4i1a1.

Himawanto. 2016b. Performa Indonesia Pada Riset Konsorsium Energi: Asesmen Bibliometrik Jurnal Ilmiah Internasional. Berkala Ilmu Perpustakaan dan Informasi, 12 (2): 91-103. https://doi.org/10.22146/bip.17287.

Himawanto. 2017. Profil Artikel Ilmiah Bidang Lingkungan di Indonesia: Analisis Bibliometrik. Lentera Pustaka, 3 (1): 27-41.

JPPN. 2017. Perguruan Tinggi Diminta Berhenti Langganan E-Jurnal. Akses di https://www.jpnn.com/news/perguruan-tinggi-diminta-berhenti-langganan-e-jurnal.

Maryatun \& Pergola Irianti. 2016. Pemanfaatan Database EBSCO dan ProQuest Sebagai Rujukan Penyusunan Tesis dan Disertasi bagi Mahasiswa Program Magister Sains dan Doktor Fakultas Ekonomika dan Bisnis UGM: Analisis Sitiran Jurnal Ilmiah. Berkala Ilmu Perpustakaan dan Informasi, 12 (2): 123-35.

Natakusumah, Engkos Koswara. 2016. Bibliometric Analysis of The Inkom Journal (Analisis Bibliometrik Jurnal INKOM). BACA: Jurnal Dokumentasi dan Informasi. 36 (1): 1-10. https://doi.org/10.14203/j.baca.v36i1.199.

Nelisa, Malta. 2012. Produktivitas Pengarang Artikel Bidang Ilmu Perpustakaan dan Informasi di Indonesia Tahun 1978-2007: Analisis Bibliometrika Menggunakan Hukum Lotka. BACA: Jurnal Dokumentasi dan Informasi, 30 (2): 73-95.

Rahayu, Sri \& Abdul Rahman Saleh. 2017. Studi Bibliometrik dan Sebaran Topik Penelitian

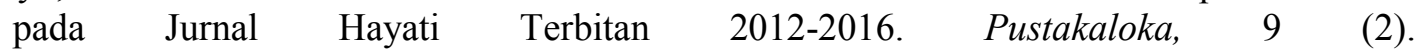
https://doi.org/10.21154/pustakaloka.v9i2.1092.

Sánchez, Amador Durán, María de la Cruz Del Río Rama, \& José Álvarez García. 2017. Bibliometric Analysis of Publications on Wine Tourism in the Databases Scopus and WoS. European Research on Management and Business Economics, 23 (1): 8-15. https://doi.org/10.1016/j.iedeen.2016.02.001.

$\begin{array}{lllll}\text { ScienceDirect. } & \text { 2018. } & \text { ScienceDirect. } & \text { January } & \text { Di }\end{array}$ https://www.sciencedirect.com/science/journals.

Scopus. 2017. Scopus Source List. Di http://www.scopus.com.

Subramanyam, K. 1983. Bibliometric Studies of Research Collaboration: A Review. Journal of Information Science, 6 (1): 33-38. https://doi.org/10.1177/016555158300600105.

Sulistyo-Basuki. 2016. Dari Bibliometrika Hingga Informetrika. Media Pustakawan, 23: 7-14.

Tupan. 2017. Analisis Saintometrik Pertumbuhan Literatur Bidang Ilmu Perpustakaan dan Informasi Berbasis Data Scopus Tahun 1996-2016. Lokakarya Nasional Dokumentasi dan Informasi. Jakarta: Pusat Dokumentasi dan Informasi Ilmiah - LIPI.

Saputra, Andi. 2018. Unand Peringkat 12 untuk Kategori PTN di Scopus. Perpustakaan Universitas Andalas. February 6. Di http://pustaka.unand.ac.id/berita-danperistiwa/item/170-peringkat-scopus. 